\title{
A Case Study Of The Integration Of Information And Communication Technology In A Northern Ontario First Nation Community High School: Challenges And Benefits
}

Gerald Laronde, Nipissing University, Canada Katarin MacLeod, St. Francis Xavier University, Canada Lorraine Frost, Nipissing University, Canada Ken Waller, Nipissing University, Canada

\begin{abstract}
A case study approach was used in examining Information and Communication Technology (ICT) use within a small First Nation high school in Northern Ontario. Quantitative and qualitative data was gathered from students, teacher, and the administrator, who participated in an online survey, followed by interviews on their use of ICT in education. How ICT was used in the classroom was examined as well as identifying the challenges and benefits. The students' benefits included easier access to research through the Internet, facilitated organization through the use of Google drive, and the use of social media. Challenges were similar to those found in in mainstream schools with concerns of technical problems, off task behavior, and improper referencing. The teacher and administrator identified barriers preventing the increased use of ICT, including the lack of professional development, resources, and Indigenous language software. The administrator recognized there was a wide skill set range among teachers in the adoption of ICT integration into their teaching. Recommendations include more professional development in ICT for teachers, additional resources for ICT, and more development of Aboriginal language software.
\end{abstract}

Keywords: Information Technology; Communication Technology; Case Study: Aboriginal Education; First Nation Education

\section{INTRODUCTION}

mproving literacy in Aboriginal communities is one step towards improving educational success (Barman, Hebert, \& McCaskill, 1986; International Reading Association, 2002). An extension of literacy is fluency in Information and Communication Technology (ICT). Today, all post-secondary institutions and most employment opportunities require skills using ICT. One of the most effective methods in achieving ICT fluency is being immersed in a ubiquitous technology program. This can be called 1:1 laptop computing, where each student has his or her own laptop computer. Most schools have computers, yet many still lack the technical infrastructure that supports effective connectivity to the Internet (Penuel, 2006). Ubiquitous laptop schools in the past have often been scrutinized and evaluated through many lenses, such as a need to justify the extra costs when compared to traditional education with books and chalkboards. The higher levels of learning that was expected from laptop teaching was often determined by test scores and often did not appear to live up to these higher expectations (Cuban, 2001; Zucker, 2008).

Previous meta-analyses completed in areas of ubiquitous computing in schools include studies in student achievement (Gulek \& Demrirtas, 2005), measurement of student writing (Goldberg, Russell, \& Cook, 2003), mathematics (Lagrange, Artigue, Laborde, \& Trouche, 2001; Li \& Ma, 2010), and pre-service teacher education 
(Kay, 2006). Interestingly, a literature search indicates little research has been completed on the implementation process of ICT using the essential conditions as proposed by ISTE (2009). The purpose of these standards, as discussed earlier by NETS Project (2007), is to leverage the use of technology in whatever form is available within the K-12 system so that students are able to learn effectively and live productively in an increasing digital society. The research presented within uses the broad themes found within the ISTE standards as a broad framework, or lens, to help guide the research questions and analysis.

The research questions for this case study are: how are the administrator, teacher, and the students using ICT? What are the advantages and disadvantages of using ICT in the class? What barriers exist in the process and support of laptop use in the schools?

\section{Setting the Context}

The participatory school is located in a First Nations community in Northern Ontario near a small urban area. The population of the high school (grades 9-12) is approximately 90 students with small class sizes. The school has a class set of portable MacBooks (24 units) and iPads (24 units). There are approximately 100 Kobos (e-books), which are occasionally used by the English class. The school has "good" Internet access with wireless throughout the school. The two classes that were visited had small numbers Class $A(N=21)$ and Class $B(N=8)$ with a total student participation number, $\mathrm{P}$, of $\mathrm{P}=17$. The majority of the students commented that they do use computer technology outside of school (88\%), many have their own devices or have access to devices outside of the school setting (82\%). At this point, students are not allowed to take school devices home, however are allowed to use their own devices when completing in-class work.

Teachers have access to and have been provided with a computer or laptop for their own use. At this particular school, a concern is the lack of content in Indigenous language software. Approximately half of the teachers at the school have participated in some form of professional development dealing with ICT. The school does have a dedicated teacher to manage ICT as well as it's own website with many teachers and students (over $50 \%$ in both cases) having school email addresses. A virtual learning environment, Google Docs, is accessible to both students and teachers outside of school hours, and is part of the school's ICT plan.

\section{LITERATURE REVIEW}

The birth rate of the Aboriginal population is one of the highest in Canada. Yet, there is still a struggle to get Aboriginal youth to complete secondary school and further post-secondary education. (Statistics Canada, 2008, 2013). Those students that do enter either college or universities require a strong digital literacy or fluency to be successful. Improving literacy in Aboriginal communities is one step towards improving educational success (Barman, Hebert, \& McCaskill, 1986; International Reading Association, 2002). An extension of literacy is fluency in ICT. Today, all post-secondary institutions and most employment opportunities require skills using ICT. One of the most effective methods in achieving ICT fluency is being immersed in a ubiquitous laptop program. This can be called 1:1 laptop computing, where each student has his or her own laptop computer (Penuel, 2006; Zucker, 2008). Most schools have computers, yet many still lack the technical infrastructure that supports effective connectivity to the Internet. These schools and communities require both supportive infrastructure (Bredin, 2001; McMahan, O’Donnell, Smith, Walmark, \& Beaton, 2011; McKeown, Noce, \& Czerny, 2007; Plante, 2005; Statistics Canada, 2008) and teachers with ICT teaching skills. The International Society for Technology in Education (ISTE) has standards for teachers (ISTE Standards, 2008) that compliment the goals and priorities of Canadian Internet Registration Authority (CIRA) (CIRA 2014), which include the enhancement of the use of the Internet for society. There exists a dearth of research in the status of ubiquitous laptop schools in Aboriginal communities (Auditor General of Canada, 2011; Human Resources and Skills Development Canada, 2013).

Previous related research in ubiquitous computing include; the adoption of new technologies (Ely, 1999; Frank, Zhao, \& Borman, 2004; Lathem, 1988; Rogers, E. M., 1963, 2003); the efficacy of laptops in education (Anderson \& Blackwood, 2004; Cuban, 1986, 2001; Goldberg, Russell, \& Cook, 2003; Hill, Reeves, Wang, Han, \& Mobley, 2004; International Reading Association, 2002; Papert, 1987; UNESCO, 2002; Urbain-Lurain, 2000; Warschauer, Grant, Del Real, \& Rousseau, 2004; Zucker, 2008); the efficacy of 1:1 laptops (Apple, 2005; Belanger, 2001; 
Bethel, Bernard, Abrami, \& Wade, 2007; Boniface \& Zucker, 2004; Brown, 2000; Brown, Burg, \& Dominck 1998; Brown \& Pettito, 2003; Penuel, 2006; Rozanski, 2002; Russell, Bebell \& Higgins, 2004; Sclater, Sicoly, Abrami, \& Wade, 2006) and identifing barriers of the adoption of ICT integration in the classroom (Karsenti \& Collins, 2011, 2012; Rogers, P. L., 1999).

The adoption of the One Laptop Per Child (OLPC) philosophy and implementation in other countries has been explored and much can be learned from these previous experiences (OLPC, 2014; Severin \& Capota, 2011). The International Society for Technology in Education (ISTE) standards and Essential Conditions provide a guideline to the successful implementation of ICT integration in schools (Hofer, 2003; Lim, 1999; ISTE, 2008; ISTE-NETS, 2004). Part of the success in ubiquitous laptop classroom includes the professional development of teachers integrating ICT into teaching (Hall \& Hord, 2006; Brinkeroff, 2006; Drazdowski, 2005; Guskey, 2000; HarveyBeavis, 2003; Kay \& Knaack, 2005; McKimmy \& Leong, 2005; Pan, 2000; Petrie, Hill, \& McCoy, 2003; Rocque \& Popham, 2002; Resta, Abraham, Gerwels, \& Tothero, 2004; van Woudenberg, 2005) Teachers graduating from a teacher education program that supports a ubiquitous environment (Kay \& Knaack, 2005). This would also include the use of laptops in Aboriginal Teacher Education Program (Peacock, Norton, \& Carbonaro, 2009). In Canada, Karsenti and Collins $(2011,2012)$ in their study of laptop schools in the Eastern Townships of Quebec examined the challenges and benefits of ubiquitous computing. An online questionnaire was used by the European Commission to determine the effectiveness of ICT use in schools in 31 countries with findings of wide variance of ICT use in members' schools (European Schoolnet, 2013).

This research entwines itself within another major body of research, Aboriginal education (Batiste, \& Barman, 1995; Frost, 2000). The term Aboriginal lumps all Indigenous people of North America together, yet there are many distinct cultures with their own languages with further differences defined by geography and proximity to larger populated areas (Dickason, 1997; Rogers \& Smith, 1994; Frideres, 1993).

If ubiquitous laptop programs can prove effective in promoting academic success of Aboriginal students, this in turn will increase the opportunities and choices available for Aboriginal students in isolated communities. As well, if ubiquitous laptop programs can prove successful in Aboriginal schools, these programs could be adopted into mainstream Canadian educational institutions.

\section{METHODOLOGY}

This case study (Baxter \& Jack, 2008) involved both quantitative and qualitative data collection (Creswell \& Plano Clark, 2007). A case study approach was used as it recognizes the uniqueness of the community defined through its geography and culture. The high school in this case study is located on a First Nations reserve populated with Aboriginal people of Ojibway descent in Northern Ontario, Canada.

The school in this article was chosen as a convenience sample with future plans to gather further data from at least three other schools in other aboriginal communities with different cultural and geographical differences to compare commonalities and differences.

The school was initially approached via the Administrator of the school to determine if ICT was being used in the school and if there was a willingness to participate in the study. Final approval to go forward with the study was contingent upon ethical approval from both the Aboriginal community and Nipissing University Ethics Board. Consideration was given to the sensitivity in working with Aboriginal people as well as young students in a high school.

Data gathering consisted of online surveys with students, teachers, and administrators using Fluidsurveys.com. The online survey link was sent to a Gmail address created by the researchers then given to and opened by the participants. This Gmail address was specifically created to maintain anonymity among the participants. It took approximately an hour of class time for the students to complete the online survey and participate in the focus group interview. Individual interviews with teachers and administrators were completed in private within a room in the school. All of the students' parents signed letters of consent prior to completion of the surveys and interviews. All participants signed letters of consent for the interviews and acknowledged consent in participating in the online 
survey. The interviews were recorded via a phone and then transcribed. A follow up visit to the school for classroom observation was conducted for triangulation. Notes were taken throughout the data gathering process. Some data analysis of the online surveys was conducted with tools from Fluidsurveys.com however sample sizes were too small for statistical analysis.

The online survey questions were loosely derived from the Survey of Schools: ICT in Education used in the European Commission carried out by European Schoolnet (European Schoolnet, 2013). In the interest of time and cultural appropriateness the survey instrument utilized was shortened and made more relevant to Aboriginal Canadians. The Essential conditions (ISTE, 2009) were considered in the construction of the survey instrument and analysis of the data.

\section{RESULTS}

The results of this case study are subdivided into the findings provided by the data gather from the administrator, teacher, and students and their respectful perceptions of the integration of ICT within their context. Findings are then connected to the ISTE standards located in Table 1 (ISTE, 2009; UNESCO, 2002). The results address the research questions; How are the administrator, teacher, and the students, using ICT? What are the advantages and disadvantages of using ICT in the class? What barriers exist in the process and support of laptop use in the schools?

\section{Administrator}

Similar to many schools across Canada, there are benefits including more student engagement with the use of laptops as technology both in and out of the classroom. It enables more student-centered learning with the teacher as more a facilitator in the classroom. The use of laptops is a benefit for students who have been identified with special needs as they can use the laptops for keyboarding with a spellcheck.

Challenges include the off task behaviour with student cell phone use in class. They initially tried a 'no cell phone use' policy but it did not work. Students were able to tap into the school Wi-Fi to use the device for games and Snapchat. This resulted in behavior problems in the classroom as well as slowing down the Internet with the amount of bandwidth usage. To address this problem, the Wi-Fi was made password protected resulting in students not being able to use their cell phones via the school's wireless network. The result of this simple change was a considerable drop in the usage of Snapchat as the students were forced to use their own data packages for any cell phone use. This decrease in pressure on the Internet increased speed for those using school provided laptops and iPads. However, the school has submitted a proposal to further increase the bandwidth of the Internet. They have wireless in the school with routers in each classroom although there are still some "dead zones" in the school as they are surrounded by cement. They are hoping that they will have fiber optic cable in the future. They do feel very fortunate that they are a school with new equipment supported with wireless and Internet.

In terms of equitable access, the administration did a trial to allow students to take the laptops home, however, in some instances inappropriate sites were accessed while the student used the laptop within the home setting. There is a firewall that exists in the school to protect against these and other inappropriate sites yet there is not that control at a student's home. The students were asked to return the laptops to the school and all were returned without issue. Due to the change of accessibility to inappropriate sites, the students are no longer allowed to remove the laptops from school property.

There were some challenges in determining the logistics for laptop distribution and keeping track of the devices. Since the school did not have enough computers for each class, they set up laptop carts. Students were able to sign the laptops out via a teacher, and although a very positive move, issues have arisen concerning the return of the laptops and them not being returned to the charging station resulting in a "dead" device.

Other issues that have become of greater prevalence according to the administration are the adoption of grammatical and syntactical errors such as the use of "gonna" and "u" as these are common abbreviations used in texting. Another concern is that some students are using the cut and paste method of writing with plagiarism being a problem. 
When examining the ISTE standards and how they compare with how and what this particular school is doing to integrate technology within the every day classroom experience, once can see from the data in Table 1, that the school from the perception of the administration is doing well.

Table 1. ISTE conditions as perceived to be met by the school administration for this study. (*FNSSP is First Nation Student Success Program)

\begin{tabular}{|c|c|}
\hline ISTE Condition & School results as offered by Administration \\
\hline Shared Vision & Yes through FNSSP $*$ mentoring. \\
\hline Empowered Leaders & Yes through FNSSP mentoring. \\
\hline Implementation Plan & Yes and modifying as required. \\
\hline Consistent and adequate funding & $\begin{array}{l}\text { Very fortunate for the funding to date. The school still has a "wish list" which includes } \\
\text { having a laptop for every child and time for teachers to create engaging lesson plans using } \\
\text { technology. }\end{array}$ \\
\hline Equitable access & $\begin{array}{l}\text { Administration and all teachers have access to their own school provided laptop. Students } \\
\text { have access to laptops or iPads while onsite. The school has a website and both teachers } \\
\text { and students have school email addresses. The school also has LMS platform accessible on } \\
\text { and off school grounds. }\end{array}$ \\
\hline Skilled personnel & $\begin{array}{l}\text { School has a teacher who is ICT coordinator but no special training other than graduating } \\
\text { from a laptop B.Ed. program. }\end{array}$ \\
\hline Ongoing professional learning & $\begin{array}{l}\text { More then } 50 \% \text { of teaching staff have participated in introductory courses and equipment } \\
\text { based courses. } 25 \%-50 \% \text { have participated in advanced courses on applications, internet } \\
\text { use, pedagogical use of ICT, subject-specific training, and peer learning communities. } \\
\text { None have participated in multi-media PD. More professional learning is desired. }\end{array}$ \\
\hline Technical support & $\begin{array}{l}\text { A teacher controls use of the ICT equipment (signing out and charging laptops and iPads). } \\
\text { An external company is contracted by the school to assist with technical repairs. }\end{array}$ \\
\hline Curriculum framework & $\begin{array}{l}\text { Infusing technology within the current subject specific areas. Two issues are the lack of } \\
\text { content in the Aboriginal language, and the lack of adequate content for teaching. }\end{array}$ \\
\hline Student-centered learning & $\begin{array}{l}\text { Advantages include level of student engagement, some students prefer it to hand-writing, } \\
\text { portability, accessibility, convenience, access to information and much less paper. }\end{array}$ \\
\hline Assessment and evaluation & Students submit work via Google Doc. Teacher knows when and who has contributed. \\
\hline Engaged community & $\begin{array}{l}\text { The teachers at the school do have scheduled time to meet to share, evaluate or develop } \\
\text { instructional materials and approaches as they relate to ICT. }\end{array}$ \\
\hline Support policies & $\begin{array}{l}\text { At the moment, the school does not have a written statement about the use of ICT. It does } \\
\text { have regular discussions with teaching staff about ICT use for pedagogical purposes, a } \\
\text { specific policy to prepare students for responsible internet behavior. }\end{array}$ \\
\hline
\end{tabular}

The 'wish list' as described by the administration would include more laptops for students to use, greater opportunity and availability for professional development for teachers, greater technical support for teachers, and more time and physical space for teachers and students to explore and use ICT. This 'wish list' would require more time and financial commitment in order to materialize. By completing the 'wish list' the school would also move further along the pathway of meeting all the ISTE conditions.

\section{Teacher}

In the beginning of the laptop use, student work was stored on jump drives, which were sometimes lost, or the student would forget the name of the file. To resolve this time consuming problem, the school initiated the use of Google Docs extensively with the students and there has been a significant improvement in student file organization. They can have a drive account where they can work on, complete, and submit assignments. Further, all the students and teachers have emails through Gmail, which allows for ease of sharing. Other teachers have agreed that the Google Docs have better organization and facilitates collaboration in that if a group of students are working on a PowerPoint they can all contribute to the final product. Once the project is completed they simply share the file with the teacher for evaluation then the teacher knows who has contributed in the collaboration and when. This would also assist in the assessment and evaluation of each of the students completing the project. Other software currently being used by the participant teacher and other teachers within the school include Live Binders, Desire2Learn, TalkingTom, and Photobooth. These applications and programs assist all students including those with special needs. 
The increase use of ICT has created a more student-centered learning environment within this teacher's classroom whereby she finds her students much more engaged. Many of the challenges previous stated by the administrator were again echoed by the teacher. These included the logistics of laptop charging and distribution of laptops at peak times, the penmanship of students has deteriorated due to a lack of required cursive writing, the increased use of texting jargon, and the increase of plagiarism, or lack of proper referencing, through cutting and pasting from online documentation.

\section{Students}

The students who participated in this research have; perhaps, the most interesting perspective of their learning with ICT as some have 'grown-up' in the $21^{\text {st }}$ century whereby the digital age is the norm. These students mainly spoke English at home with a small number also speaking Ojibway or Cree. Many (82\%) used computer technology outside of school, primarily at home, and also had access to the Internet at home (94\%). These students (82\%) have been using computer technology for more then 3 years and are active online indicating that they use the internet for social networking (Facebook, Instagram, Twitter), search online for information, watching video clips, downloading music, and playing computer games. Students are using technology while in the classroom, for instance, most have used a laptop, tablet, or mobile phone ( $82 \%$ ) in class and $76 \%$ commented that they use the Internet everyday while at school. They also commented that Interactive whiteboards (Mimeo or Smartboards) are used at least once a week during their classes. They are being asked to create Powerpoints, podcasts, and play digital learning games at least once a week. They are searching the Internet for information almost every day while in school and are engaged at working on an individual assignment or working in small groups using ICT at least once a week. The majority had been taught keyboarding skills within the school setting with an average speed of 39 words per minute, as reported by the students.

Interestingly, although these students are using ICT frequently within school and outside of school, their confidence in preforming various tasks is not high. Only half of the students felt confident or very confident in using word processing, editing a digital photo, saving files, creating a presentation, participating in a blog, installing software, or keeping files organized. More then $50 \%$ felt confident in their ability to use the internet safely, respect the privacy and reputation of others, and in their ability to judge the accuracy of information found on the internet. Almost $50 \%$ commented that they had been victims of cyber bullying and $20 \%$ commented that they had participated in cyber bullying.

When considering if ICT "helps" students in the classroom, approximately half commented that they concentrate more on what they are learning, that they try harder, they feel more independent, they understand and remember more, assists with working with others and improves overall the classroom learning environment. The other half were uncertain if ICT was effective in these areas. The students were also asked about their perceptions concerning the connection between learning and being proficient using ICT and employment opportunities. Interestingly, they did not see a connection or correlation between the two and it is not known why this connection was not made. Finally, the group of students were split on the influence of ICT as a learning tool with respect to their culture. Only $35 \%$ said that ICT has allowed them to learn about their culture whereby $65 \%$ commented that it has not.

\section{RECOMMENDATIONS}

The teacher and administrator have requested more funds to purchase more laptop computers. Their goal would be to provide a laptop for every child entering the school and the student would then own the computer after graduating. After four years the laptop would probably need to be replaced or updated anyway. This would be an incentive for the students to complete high school, as well as having gained ICT fluency during the years at school. Professional development opportunities for teachers in the integration of ICT into teaching were also requested. There did exist a wide range of ICT abilities among teachers and professional development may improve the skills of willing teachers and provide opportunities for more development in a world where ICT development continues at exponential rates. 


\section{CONCLUSION}

The findings from this particular case are similar to the benefits and challenges of other schools that have adopted ubiquitous computing. From the data provided, this school is working hard to include the ISTE standards and is seeing success in certain areas, knowing that there is room for improvement in others. The teachers would like to have more professional development and the school, overall, would like to be able to give each student a laptop, which they could keep at the end of grade 12. A concern of this particular school, voiced by the administration, teacher, and students was the lack of software that would connect the students to their language, Ojibway, and to their culture.

\section{AUTHOR BIOGRAPHIES}

Gerald Laronde, $\mathrm{PhD}$ is an assistant professor at Nipissing University, in North Bay, Ontario, Canada. He teaches Physics, Chemistry, and Science Education as well as Technology Enriched Teaching and Learning in the Faculty of Education. He has previously taught at the elementary, secondary, and college levels.

Katarin MacLeod, PhD is an associate professor with the Faculty of Education at St. Francis Xavier University. She teaches Bachelor of Education secondary science methods courses, middle school mathematics methods courses, Masters-level research methods courses as well as special topics in science education, specifically STSE/STEM in $21^{\text {st }}$ century science classroom within the Department of Leadership and Curriculum. She teaches "Teaching and Learning in the Physical Sciences" course within the departments of Physics and Chemistry. Her areas of research includes Physics Education Research (PER), Science, Technology, Society and Environment (STSE) and Science, Technology, Engineering, and Mathematics (STEM) infusion into the $21^{\text {st }}$ century classroom. She was the recipient of the 2012-2013 Canadian Science Education Research Group (SERG) Dissertation award for the most outstanding science education dissertation in Canada. She is currently working on projects that include exploring ubiquitous laptop/tablet learning in northern communities, legal ramifications of safety training of preservice science teachers, and improving the digital literacy of pre-service and in-service science teachers to enhance learning and meet STSE/STEM curriculum outcomes.

Lorraine Frost, $\mathrm{PhD}$ is an associate professor at Nipissing University She teaches Special Education as well as Master of Education and $\mathrm{PhD}$ courses in the Faculty of Education. Lorraine has both teaching experience accompanied with extensive research on First Nation Schools. Presently, Lorraine is the Chair of Graduate Studies.

Ken Waller, B.Ed., M.Ed., has taught in the elementary system and has taught teachers how to use technology at Nipissing University.

\section{REFERENCES}

Apple (2005). Research: What it says about 1:1 learning. Retrieved from http://ubiqcomputing.org/Apple_1-to-1_Research.pdf.

Alberta Education (2010). Emerge one-to-one laptop learning initiative: Final report. Retrieved from http://www.education.alberta.ca/admin/technology/emerge-one-to-one.aspx.

Auditor General of Canada (2011). 2011 June Status Report of the Auditor General of Canada: Chapter 4- Programs for First Nations on Reserves. Retrieved from http://www.oag-

bvg.gc.ca/internet/English/parl_oag_201106_04_e_35372.html\#hd5e.

Barman, J., Hebert, Y., \& McCaskill, D. (1986). The legacy of the past: An overview. In J. Barman, Y. Hebert, \& D. McCaskill, (Eds.), Indian Education in Canada: Volume 1: The Legacy (pp. 1-22). Vancouver: University of British Columbia Press.

Batiste, M., \& Barman, J. (Eds.). (1995). First Nations education in Canada: The circle unfolds. Vancouver: UBC Press.

Brown, D. G. (2000). The jury is in. In D. G. Brown (Ed.), Teaching with technology. (pp. 4-5). Bolton, MA: Anker Publishing Company.

Brown, D. G., \& Petitto, K. R. (2003). The status of ubiquitous computing. Educause Review: May/ June, pp. 25-33. Retrieved from http://www.educause.edu/ir/library/pdf/erm0331.pdf.

Creswell, J. W., \& Plano Clark, V. L. (2007). Designing and conducting mixed methods research. Thousand Oaks, CA: Sage Publications.

Cuban, L. (2001). Oversold and underused: Computers in the classroom. Cambridge, MA: Harvard University Press. 
Dickason, O. P. (1997). Canada's First Nations: A history of founding peoples from earliest times (2 ${ }^{\text {nd }}$ ed.). Toronto: Oxford University Press Canada.

European Schoolnet (2013). Survey of schools ICT in education: Benchmarking access, use and attitudes to technology in Europe's schools (2013). Luxembourg: Publications Office of the European Union.

Fitz-Gibbon, C. T., \& Morris, L. L. (1987). How to design a program evaluation. Newbury Park, CA: Sage Publications.

Fitzpatrick, K. A. (1998). Program evaluation handbook: A comprehensive guide for standards-based program evaluation for schools committed to continuous improvement. Schaumburg, IL: National Study of School Evaluation.

Frideres, J. S. (1993). Native peoples in Canada: Contemporary conflicts. Scarborough, ON: Prentice-Hall Canada.

Frost, L. G. (2000). Assessing First Nations Students. Canadian Society for Studies in Education. Edmonton, Alberta.

Gulek, J. C., \& Demrirtas, H. (2005). Learning with technology: The impact of laptop use on student achievement. Journal of Technology, Learning and Assessment 3(2), 4-38.

Goldberg, A., Russell, M., \& Cook, A. (2003). The effect of computers on student writing: A meta-analysis of studies from 1992 to 2002. Journal of Technology, Learning, and Assessment, 2(1) 1-52.

Human Resources and Development Canada (2013). Indicators of Well-Being in Canada. Retrieved from: http://www4.hrsdc.gc.ca/.3ndic.1t.4r@-eng.jsp?iid=29

International Reading Association (2002). Integrating literacy and technology in the curriculum: A position statement of the International Reading Association. Retrieved from http://www.reading.org/Libraries/Position_Statements_and_Resolutions/ps1048_technology.sflb.ashx

ISTE NETS. (2008). National Education Technology Standards (NETS-T) and Performance Indicators for Teachers. Retrieved from http://www.iste.org/Content/NavigationMenu/NETS/ForTeachers/2008Standards/NETS_T_Standards_Final.pdf

ISTE NETS. (2009). Essential conditions. Retrieved from http://www.iste.org/docs/pdfs/netsessentialconditions.pdf?sfvrsn=2

Kay, R. H. (2006). Evaluating strategies used to incorporate technology into preservice education: A review of the literature. Journal of Research on Technology in Education; 38(4), 383.

Lagrange, J., Artigue, M., Laborde, C., \& Trouche, L. (2001). A meta study on IC Technologies in education: Towards a multidimensional framework to tackle their integration. In PME Conference (1), 1-111. Retrieve from http://didmat.dima.unige.it/miur/miur_dima/G/STORIA DI_UNA RICERCA/LAGRANGE.PDF

Li, Q. \& Ma, X. (2010). A meta-analysis of the effects of computer technology on school students' mathematics learning. Educational Psychology Review. 22(3), 215-243.

Ontario Ministry of Education. (2006). The Ontario Curriculum Grades 9 and 10: Business Studies. Retrieved from http://www.edu.gov.on.ca/eng/curriculum/secondary/business910currb.pdf.

Patton, M. Q. (2012). Essentials of utilization-focused evaluation. Thousand Oaks, CA: Sage Publications.

Penuel, W. R., (2006). Implementation and effects of one-to-one computing initiatives: A research synthesis. Journal of Research on Technology in Education, 38(3), 330-348.

Posavac, E. J. \& Carey, R. G. (2007). Program Evaluation: Methods and case studies (7th ed.). Upper Saddle River, NJ: Pearson Prentice-Hall.

Rogers, E. S., \& Smith, D. B. (1994). Aboriginal Ontario: Historical perspectives on the First Nations. Toronto: Dundurn Press Ltd.

Rogers, H. (2006). The status of elementary keyboarding: A longitudinal study. Retrieved from http://facstaff.uww.edu/rogersh/keyresearch/elemkeymanu2006.doc

UNESCO. (2002). P. Resta (Ed.). Information and communication technologies in teacher education: A planning guide. UNESCO, Paris: Retrieved from http://unesdoc.unesco.org/images/0012/001295/129533e.pdf

Zucker, A. A. \& Hug, S. T. (2008). Teaching and learning physics in a 1:1 laptop school. Journal of Science Education and Technology. 17(6), 586-594. 